BIBLIOTEKA 2018, NR 22 (31)

PL ISSN 1506-3615

DOI: $10.14746 / \mathrm{b} .2018 .22 .11$

\title{
IULIANA GRAŻYŃSKA
}

Uniwersytet im. Adama Mickiewicza w Poznaniu, Biblioteka Uniwersytecka

\section{Kongres AMMLA 2017 w Londynie}

Streszczenie. Artykuł podsumowuje 27. kongres naukowy AMMLA (Europejskiego Stowarzyszenia Muzeów, Bibliotek i Archiwów Wolnomularskich) zorganizowany w Londynie z okazji 300. rocznicy powstania masonerii angielskiej.

Słowa kluczowe: AMMLA Congress 2017, Freemasonry, Freemason's Hall, The Library and Museum of Freemasonry, Chiswick House, Wolnomularskie Zbiory Muzyczne w Bibliotece Uniwersyteckiej w Poznaniu.

Z okazji obchodówów 300. rocznicy powstania masonerii angielskiej w dniach 6-9 lipca 2017 roku w Londynie odbył się 27. kongres naukowy AMMLA (Europejskiego Stowarzyszenia Muzeów, Bibliotek i Archiwów Wolnomularskich).

Biblioteka Uniwersytecka w Poznaniu, jako instytucja świecka, ale dysponująca jedną z największych kolekcji druków wolnomularskich i będąca od 2012 roku pełnoprawnym członkiem stowarzyszenia AMMLA, została zaproszona do udziału w jubileuszowym kongresie zorganizowanym przez The Library and Museum of Freemasonry ${ }^{1}$.

Wielką Loże Narodową Polski reprezentował wielki mistrz honorowy dr hab. Tadeusz Cegielski, prof. nadzw. Uniwersytetu Warszawskiego.

W dniu otwarcia kongresu, 6 lipca, zaszczycił nas swoją obecnością także reprezentant lóż londyńskich z obediencji Russelle Race. Po okolicznościowym toaście mieliśmy okazję obejrzeć wystawę zorganizowaną w Bibliotece i Muzeum Wolnomularstwa (Library and Museum

1 AMMLA jest jedynym w Europie forum, na którym pracownicy tej wyspecjalizowanej dziedziny mogą się spotkać i wymieniać doświadczenia. W związku z tym jest jedyną organizacją która może się podjąć zadania koordynacji digitalizacji druków i dokumentów wolnomularskich znajdujących się w muzeach, bibliotekach i archiwach europejskich. Przewodniczącym AMMLA jest François Rognon, reprezentant Musée-Archives-Bibliothèque France / Grande Loge de France, który zastąpił Rolanda Hankego, dyrektora Deutsches Freimaurermuseum Bayreuth. 

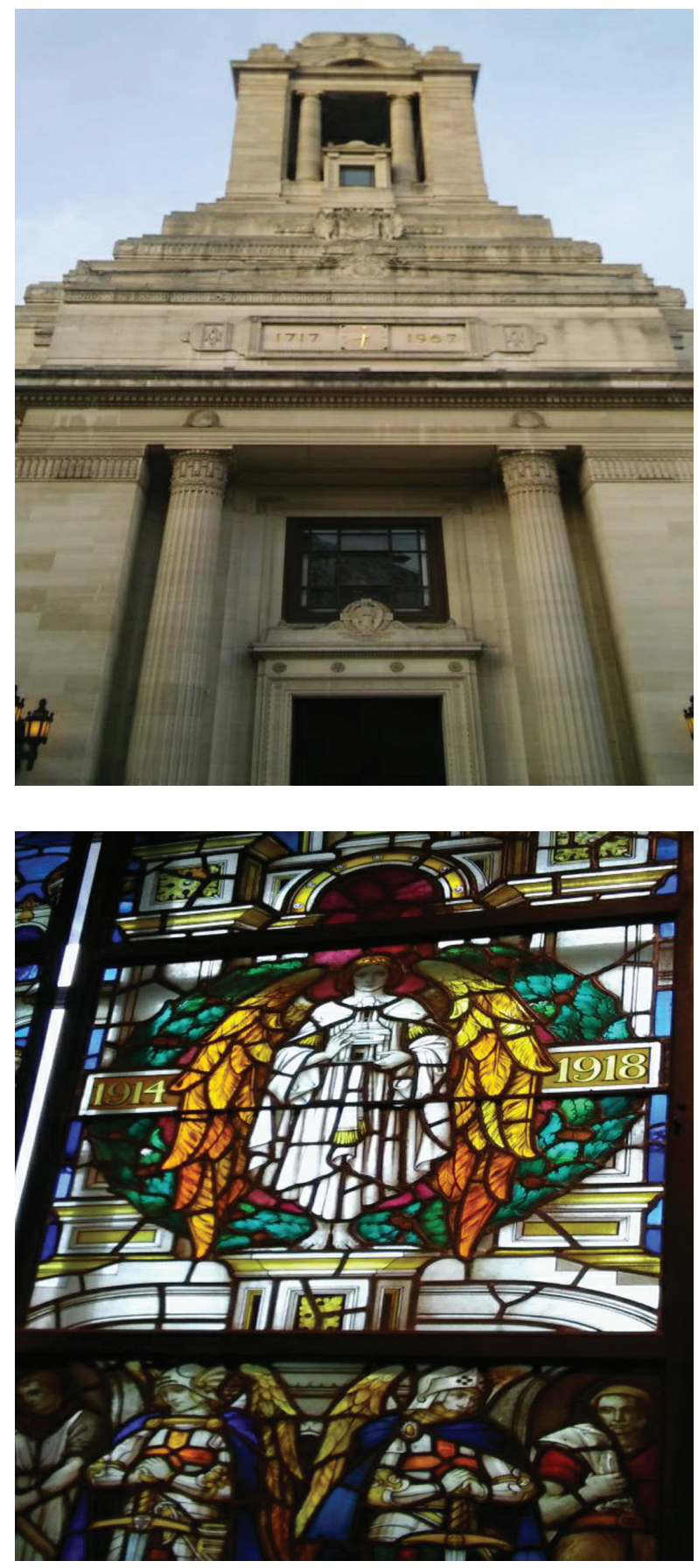

Fot. 1-2. Freemason's Hall Fot. Iuliana Grażyńska. 
of Freemasonry) oraz posłuchać fragmentów muzyki wolnomularskiej w loży wielkiego mistrza, księcia Kentu.

Następnego dnia miała miejsce wizyta Wielkiej Loży (Grand Lodge) w prowincji Middlesex, w miejscowości Twickenham. Rozpoczęły się też obrady.

8 lipca referaty uczestników konferencji kontynuowano w Londynie, w siedzibie Freemason's Hall. Freemason's Hall mieści się na Great Queen Street i od 230 lat jest centrum Wielkiej Zjednoczonej Loży Anglii (United Grand Lodge of England), najstarszą lożą na świecie oraz miejscem spotkań ponad 1000 lóż. Przebudowany w klasycznym stylu art deco w 1933 roku budynek przyciąga zarówno laików, jak i znawców tematu wolnomularstwa.

Biblioteka posiada niezwykłe historyczne dziedzictwo uznane przez Museums, Libraries and Archives Council za wyjątkową jakość historyczną. Jej zbiory wynoszą 64 tys. woluminów oraz ok. 2,5 km archiwum. Natomiast w Muzeum Wolnomularstwa można zobaczyć 25 tys. cennych zabytków związanych z dziejami wolnomularstwa od XIV do XX wieku: obiekty rytualne, regalia, ubiory, pamiątki.

Oficjalna historia wolnomularstwa zaczyna się 24 czerwca 1717 roku, kiedy w małej gospodzie pod Gęsią i Rusztem cztery istniejące loże połączyły się w Wielką Lożę Londynu.

To było terminus a quo 4 tys. lat legendarnej historii wolnomularstwa. Nowych członków nazwano wolnomularzami "spekulatywnymi" (niezajmującymi się czynnie budownictwem), w odróżnieniu od wolnomularzy "operatywnych”, którzy stali się wówczas mniejszością.

$\mathrm{Na}$ początku kongresu, podążając szlakiem symboliki wolnomularskiej, złożyliśmy wizytę w wolnomularskim muzeum, w miejscowości Chiswick, ok. $10 \mathrm{~km}$ od Londynu. Wzniesiona tam willa w stylu architektury neo-palladiańskiej, licząca prawie 300 lat, zawdzięcza swoje istnienie Richardowi Boyle'owi Trzeciemu, zwanemu lordem Burlingtonem. Wspomniany w konstytucjach Jamesa Andersona z 1723 i 1738 roku lord Burlington był wszechstronnym brytyjskim architektem, który w swoich projektach inspirował się Wielkim Architektem Świata. Należał do ruchu architektury wolnomularskiej i razem z Williamem Kentem stworzył osobliwy obszar, natchniony dziełami weneckiego Andrei Palladia. Po podróży Grand Tour po Europie szczególną uwagę Richarda Boyle’a zwróciły Włochy, skąd przywiózł imponującą kolekcję włoskich skarbów XVIII-wiecznej sztuki, która wypełnia zarówno pomieszczenia Chiswick House, jak i otaczające je ogrody. W obu przestrzeniach, silnie nasyconych symboliką wolnomularstwa, można dostrzec dzieła oparte na Świątyni Salomona, z jej forma, cechami, kolumnami Jachin i Boaz, 

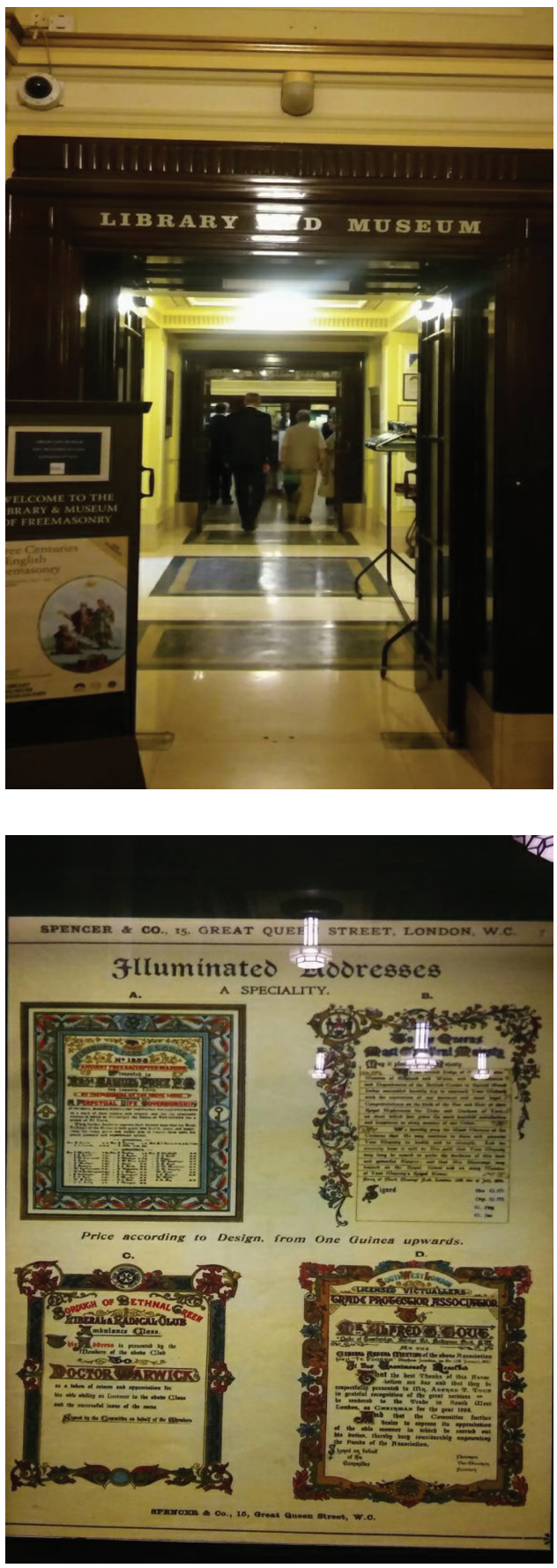

Fot. 3-4. Biblioteka i Muzeum Wolnomularstwa Fot. Iuliana Grażyńska. 
wraz z symbolami egipskimi, ruinami budynków rzymskich i greckich, noszących typowe wolnomularskie nazwy, takie jak Swiątynia Przyjaźni, Cnoty, Mądrości.

Dawniej willa funkcjonowała jako budynek ogrodowy. Można sobie wyobrazić pokój pełen kwiatów otwierający się na piękny ogród pełen oczek wodnych. Być może była to także siedziba prywatnej loży wolnomularskiej. Tam spotkali się: Alexander Pope, Jonathan Swift, Isaac Ware i książę Grafton. Willa gościła znakomite koronowane głowy: królową Wiktorię z mężem Albertem, cara Mikołaja I, króla Prus czy królową Marię. Od roku 1984 Chiswick House stał się własnością organizacji English Heritage i jest udostępniony do zwiedzania.
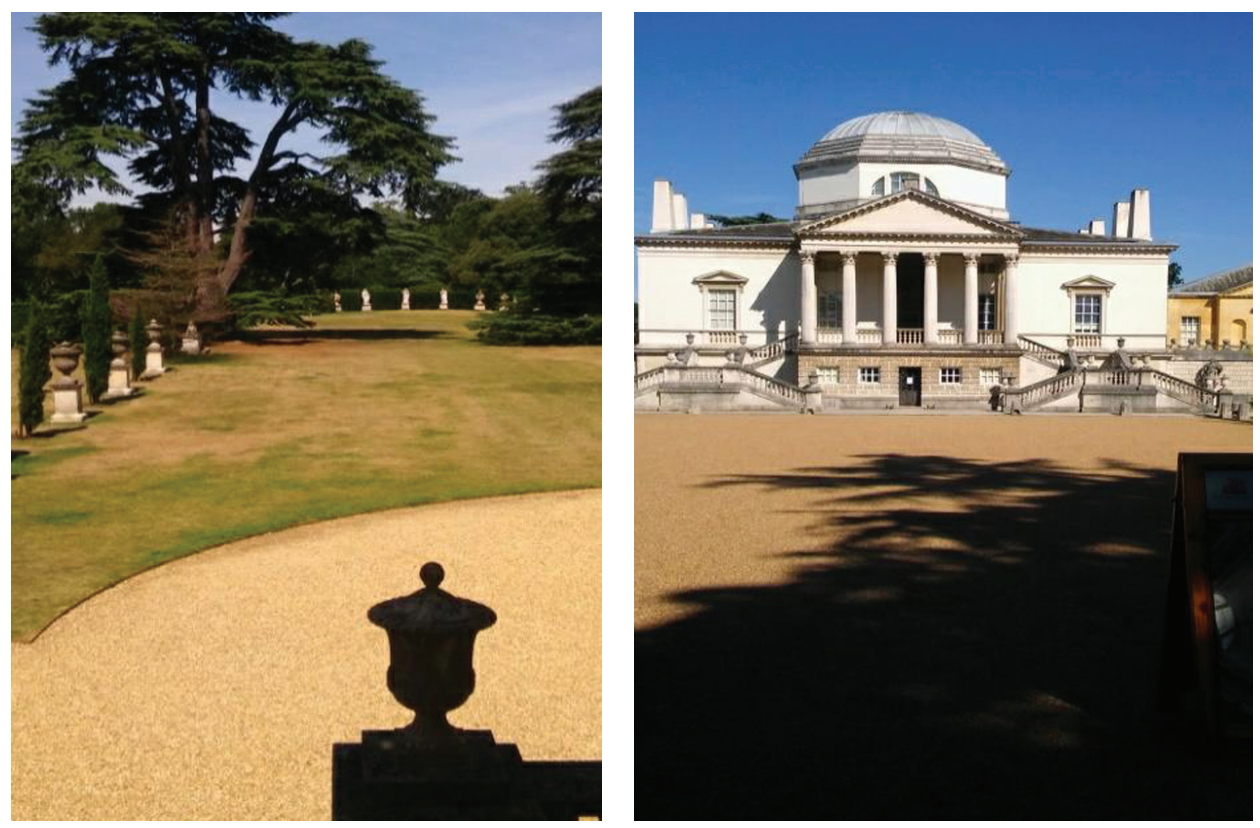

Fot. 5-6. Chiswick House

Fot. Iuliana Grażyńska.

Wnętrza zostały zrekonstruowane wraz z piękną kolekcją mebli w stylu palladiańskim oraz wspaniałymi sufitami i wnękami. Każdy pokój reprezentuje inny żywioł, a także bogatą symbolikę wolnomularską. Pokój zielony ma przypominać o naturze i jej pięknie, pokój błękitny o sztuce i architekturze, pokój czerwony jest żywiołem ognia, a galeria odwołuje się do symboliki wodnej.

Niebieski Aksamitny Pokój jest odniesieniem do Świątyni Jerozolimskiej jako doskonały sześcian. Był to „pokój rysunku” lorda Burlingtona. 

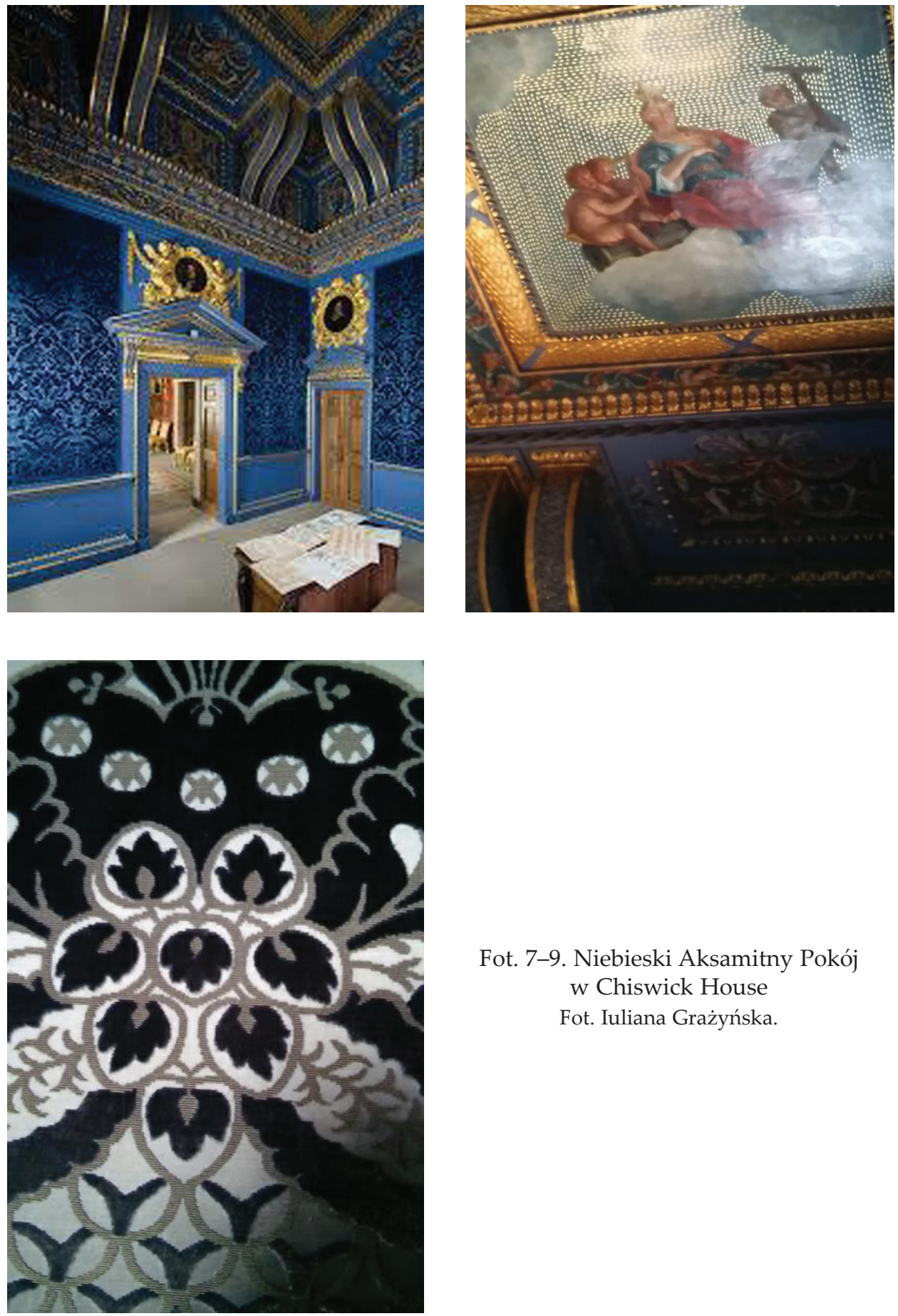

Fot. 7-9. Niebieski Aksamitny Pokój w Chiswick House

Fot. Iuliana Grażyńska. 
Tu mieścił się stół Williama Kenta, który zawierał wiele projektów architektów, takich jak Andrea Palladio, Inigo Jones, John Webb i Vincenzo Scamozzi. Sufit pomalowany przez Williama Kenta jest świadectwem zamiłowania lorda Burlingtona do architektury. W centrum przedstawia spersonifikowaną Architekturę i trzy aniołki, które chwytają narzędzia architektoniczne: poziomicę i pion. Cały sufit otacza dekoracja, którą można interpretować jako przesłanie masońskie, narzędzia te były bowiem symbolami moralności. Aniołek po lewej stronie, jeden z muz Architektury, trzyma palec przy ustach, sugerując ciszę lub tajemnicę. Ściany wyłożone niebieskim aksamitem zawierają symbole cyrkla i węgielnicy.
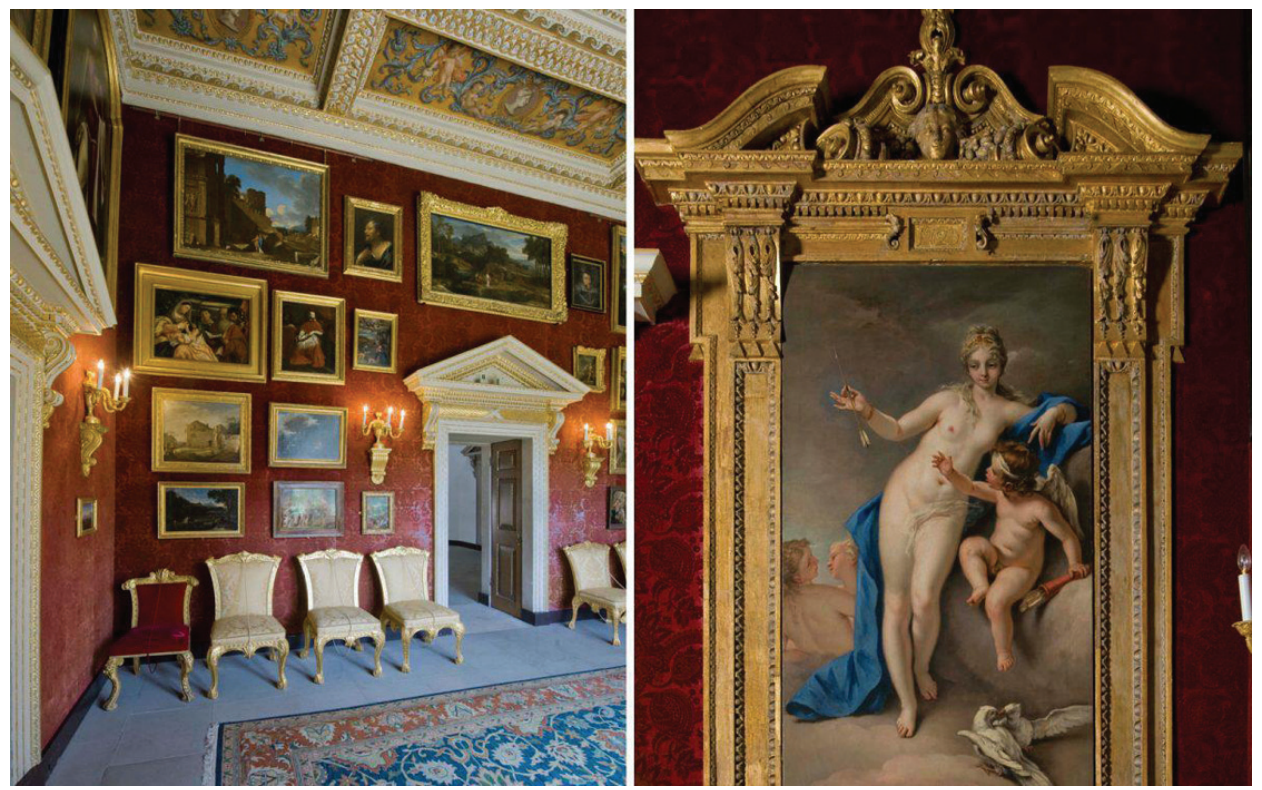

Fot. 10-11. Czerwony Aksamitny Pokój w Chiswick House

Źródło:http://chiswickhouseandgardens.org.uk/house-gardens/the-house/explore-the-state-roo $\mathrm{ms} /$.

Czerwony Aksamitny Pokój jest jednym z najbardziej luksusowych pokoi gościnnych lorda Burlingtona. Całe ściany pokryte są wspaniałymi pejzażami.

Marmurowy komin wokół otworu paleniska otulony jest sztukaterią z elementami różanymi, szkockim ostem, przedstawieniami winogron, słoneczników, jabłek, granatów i fleur-de-lys, które można interpretować jako symbole Jakuba. Na ramach widnieje data: 1729.

Sufit pokoju czerwonego zdobią malowane przez Williama Kenta panele. Panel centralny przedstawia Merkurego oraz muzy i stanowi 
wizualną deklarację roli Burlingtona jako patrona sztuki. Merkury kieruje róg obfitości na postacie kobiece reprezentujące sztuki wizualne - architekturę, rzeźbę i malarstwo.

Wokół centralnego malarstwa znajduje się sześć ciał niebieskich: Wenus, Słońce, Mars, Jowisz, Saturn i Księżyc z powiązanymi znakami zodiaku. Siódmą planetę - Merkurego umieszczono na środku; towarzyszą mu konstelacje Bliźniąt i Panny. Jest to ważny obraz wszechświata. W centrum znajduje się ośmioramienna gwiazda Orderu Podwiązki, jedno z najwyższych odznaczeń brytyjskich, które lord Burlington otrzymał od króla Jerzego II w 1730 roku. Gwiazda reprezentuje Słońce w najdłuższym dniu roku, dniu przesilenia letniego, który wolnomularzom kojarzy się z ich patronem - św. Janem Chrzcicielem.

Zielony Aksamitny Pokój był również miejscem wystawiania cennych obrazów. Dziś pokoje te składają się z sześciu obrazów ogrodów autorstwa flamandzkiego artysty Pietera Andreasa Rysbracka. Obrazy te są szczególnie wartościowe, ponieważ ukazują rozwój ogrodów w czasach Burlingtona, Kenta i Papie. W pokoju tym znajduje się także obraz George'a Lamberta, uważanego przez historyków sztuki za przedstawiciela angielskiego malarstwa krajobrazowego. Na kominku można zobaczyć wyrytego w marmurze Zielonego Człowieka, pogańskiego boga, będącego symbolem odrodzenia i zmartwychwstania.

Ciekawym pomieszczeniem jest galeria nazywana Salą Wodną. Składa się z dwóch okragłych pokoi z półkopułami zdobionymi złotymi ornamentami i kolumn. Na prostokątnych białych ścianach znajdują się kopie fresku autorstwa Paola Veronesego The Defence of Scutari. Można podziwiać zaprojektowane dla tego domu przez Kenta mahoniowe krzesła i dwa stoły z lustrami oraz inkrustowane blaty z 22 różnymi rodzajami marmuru; obramowane geometrycznym kształtem meandry symbolizują żywioł wody. W pokoju znajduje się również rzeźbiona pozłacana podstawa, która fascynuje swoimi symbolami wodnymi: muszelki dla Neptuna i Wenus oraz dwie nimfy morskie pokryte łuskami, trzymające perły.

O finezji Chiswick House świadczą nie tylko zabytki, ale także dumnie przechadzający się po parku mieszkańcy - wymarzona sceneria dla niejednego reżysera. Oranżeria, Burlington Lane Gate, włoski ogród, wodospad czy eksedra greckich rzeźb to tylko przedsmak prawdziwej uczty dla zwiedzających. Wizyta w Chiswick House była pasjonującym doświadczeniem. Bez wątpienia jest to perełka sztuki wolnomularskiej i dziedzictwa kulturowego.

Jubileuszowy londyński kongres zjednoczył reprezentantów największych bibliotek i archiwów wolnomularskich w USA i w Europie, w tym 


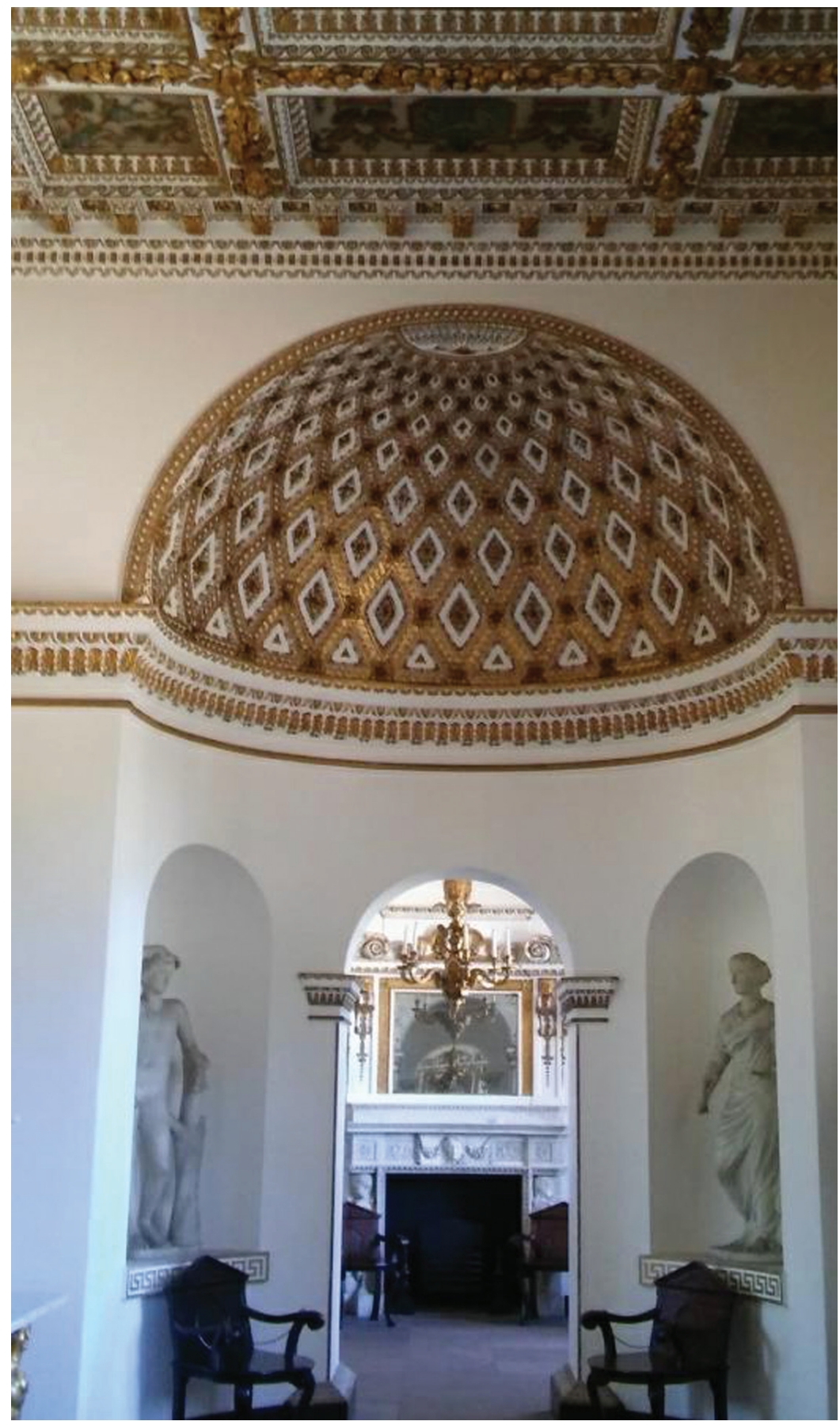

Fot. 12. Galeria w Chiswick House Fot. Iuliana Grażyńska. 
dyrektorów bibliotek z: Pensylwanii, Bayreuth, Berna, Brukseli, Bukaresztu, Korfu, Hagi, Londynu, Oslo, Paryża, Pragi, Rosenau.

$\mathrm{Z}$ tej okazji referaty zaprezentowali:

1. Roland Hanke (Deutsches Freimaurermuseum), Quiz for masons and non-masons - a possibility to involve visitors with freemasonry on daily items (Quiz dla masonów i niemasonów dot. zainteresowania zwiedzających symbolika wolnomularska przedmiotów codziennego użytku).

Symbole stosowane w sztuce jako elementy reprezentujące kanony oraz charakter epoki obecnie są także przymiotem wielu organizacji chcących identyfikować swój unikalny wizerunek z precyzyjnie wyselekcjonowanym znakiem charakterystycznym dla danej marki i jednocześnie szeroko rozpoznawalnym w społeczeństwie. Przykłady zostały zaprezentowane podczas referatu, w którym Roland Hanke zaznaczył obecność symboli wolnomularskich wśród wielorakich produktów. Poza wybranymi znakami drogowymi, m.in. zakazem postoju, są to także loga Coca-Coli, KFC, Coco Chanel, Davidoff, Gillette czy nawet wizerunek Waszyngtona na banknocie dolarowym. Obecnie symbolika jako dziedzina wciąż ewoluuje na potrzeby modernizacji udogodnień komfortu życia codziennego, funkcjonuje też jako pośrednik $\mathrm{w}$ przekazywaniu wartości wychowawczych. Wolnomularze, wykorzystując zasób słów oraz symboli zapożyczonych z różnorodnych kultur, a posiadających wielorakie znaczenia, poprzez ich kompilacje stworzyli system ułatwiający edukację.

2. Max Palla (Freimaurermuseum Schloss Rosenau) zaprezentował historię wolnomularskiego muzeum.

Budynek Schloss Rosenau pochodzący z 1590 roku w połowie XVIII wieku stał się siedzibą loży masońskiej. Jednak w 1795 roku ruch wolnomularski został zakazany, a wszystkie loże rozwiązano. Zniszczony budynek w 1964 roku doczekał się renowacji, a badania konserwatoryjne pozwoliły na rozpoznanie przeszłości pomieszczeń i ich funkcji dla lóż. Aktualnie Schloss Rosenau funkcjonuje jako hotel i muzeum.

3. Tadeusz Cegielski (Warsaw University), In the Valley of Vistula. Freemasonry and Its Legacy in Polish Museums, 1995-2015 (W Dolinie Wistuty. Spuścizna wolnomularska w polskich muzeach, 1995-2015).

Referat zbudowany na 66 slajdach jest dokumentacją powstałych w ciągu 20 lat wystaw wolnomularskich zorganizowanych w Polsce.

4. Louise Pichel (Library-museum GL England), Illuminated masonic addresses from across Europe (Iluminowane dyplomy wolnomularskie w catej Europie).

Dzięki tej prezentacji mieliśmy okazję poznać najcenniejsze dyplomy, certyfikaty, zwoje, nagrody, a także dokumenty wolnomularskie 
znajdujące się w wielkim archiwum Biblioteki i Muzeum Wolnomularstwa w Londynie.

5. Helge Bjørn Horrisland (GL), Norway archives - Update on restitution issues 2016-2017 (Archiwa Norwegii - aktualizacja dotyczaca kwestii restytucji na lata 2016-2017).

Reprezentant Norwegii, archiwista Wielkiej Loży Norwegii miał okazję uczestniczyć w kilku europejskich masońskich projektach repatriacyjnych i odzyskać znaczną część zrabowanych druków. Na podstawie przeprowadzonych badań stworzył realny obraz tego, co wydarzyło się podczas II wojny światowej z wolnomularskim „Holokaustem kulturalnym". Horrisland omówił pozyskiwanie kolekcji wolnomularskich z rozproszonych europejskich archiwów ${ }^{2}$. W Archiwum Państwowym w Szczecinie znajduje się kartoteka przedstawiająca członków lóż, niestety nie jest ona dostępna. Z kolei w Niemczech w Bawarskiej Bibliotece Państwowej jako przykład podano kompletną listę bibliotek lożowych zidentyfikowanych jako właściciele książek masońskich. Wszystkie książki zostały przesłane do Biblioteki Państwowej z magazynów Reichssicherheitshauptamt $\mathrm{w}$ zamian za dokumenty przekazane do SS-Schule Haus Wewelsburg. W Republice Czeskiej Biblioteka Narodowa sporządziła raport na temat zrabowanych z niej książek. W Neratovicach, gdzie znajduje się ok. milion książek, zidentyfikowano 6 tys. woluminów masońskich należących do 109 lóż.

Obecnie w trakcie realizacji jest kilka projektów, takich jak: The Afanassiev List, State Historical Public Library, Moscow National Library, Minsk SD-Karthotek, State Archive Szczecin, German Libraries Exhibition, Ossietzky University, Hamburg Masonic Books czy National Library Prague.

6. Iuliana Grażyńska (Biblioteka Uniwersytecka w Poznaniu), Music masonic collection in the University Library of Poznan (Wolnomularskie zbiory muzycznie w Bibliotece Uniwersyteckiej w Poznaniu).

W zbiorach muzycznych i wolnomularskich w Bibliotece Uniwersyteckiej w Poznaniu zgromadzono setki partytur i tekstów muzycznych $\mathrm{w}$ różnych językach. Te zbiory pozwoliły na zorganizowanie koncertu podczas kongresu AMMLA w Ciążeniu w lipcu 2014 roku. W jego wyniku zainteresowanie muzyką wolnomularską zauważalnie wzrosło. Udało się zdobyć książki, których nakłady były wyczerpane od dłuższego

2 W 2010 roku Pracownia Zbiorów Masońskich Biblioteki Uniwersyteckiej przekazała Bibliotece Wielkiej Loży Norwegii ok. 500 woluminów należących do tej biblioteki. Te książki były zrabowane przez RSHA w czasie II wojny i odnalezione w zbiorach zabezpieczonych w Sławie Śląskiej. Przekazanie p. Horrislandowi książek znalezionych w Bibliotece Uniwersyteckiej w Poznaniu zakończyło akcję zwracania książek norweskich. 
czasu, np. Frank-Massonia mężczyzn i kobiet symboliczna (tłumaczenie książki Cérémonies et coutumes religieuses) oraz Pieśnik wolnomularski, edytowany przez Tadeusza Wolańskiego. Oba teksty stanowią bezcenny materiał dla polskich historyków wolnomularstwa. Pierwsze wydanie ukazało się w roku 1820. Niestety po rozwiązaniu ruchu wolnomularskiego w 1821 roku przez cara Aleksandra I w Rosji i jej krajach zależnych wolnomularska literatura poetycka i artystyczna w Polsce zniknęła. Na początku XX wieku Stanisław Małachowski-Łempicki, badacz literatury masońskiej, podał ponad 80 nazwisk polskich muzyków wolnomularskich. Najbardziej aktywnym kompozytorem był Józef Antoni Franciszek Elsner (członek Master of Music w Halle der Beständigkeit), twórca ok. 400 kompozycji muzycznych. Szacuje się, że z XVIII i XIX wieku brakuje jednej piątej literatury poetyckiej.

7. Martin Cherry (Library-museum GL England), Illustrating the Constitutions (Ilustrowane konstytucje).

Ważną częścią księgozbioru Biblioteki i Muzeum Wolnomularstwa w Londynie są konstytucje, wśród nich konstytucje Andersona, najbardziej znany dokument wolnomularski. Ta księga jest dokumentem określającym zasady moralne, których każdy członek loży wolnomularskiej na świecie powinien przestrzegać.

8. Viorel Danacu (Regional Center for Masonic Studies Paris - Bucharest), Romania centenary, 100 years from the great union and the influence of freemasonry (1918-2018) (Stulecie Wielkiego Zjednoczenia Rumunii i wptyw wolnomularstwa (1918-2018)).

Prezentacja dotyczyła nadchodzącego jubileuszu stulecia proklamacji Wielkiego Zjednoczenia organizowanego w Alba Iulia. Z okazji okragłej rocznicy Rumunia przygotowuje setki wydarzeń. Autor podkreślił znaczącą rolę delegacji rumuńskich wolnomularzy na konferencji pokojowej w Trianon.

9. Spiros Andriotis (Phoenix Freemasonic Museum Corfu) zaprezentawał nowo powstałe muzeum, w którym będzie odbywał się kongres AMMLA w 2018 roku.

W dyskusjach na temat zaprezentowanych referatów wzięli udział: Rognon François (prezes AMMLA, GL de France Musée-Archives-Bibliothèque), Clemens Diane (dyrektor Library and Museum of Freemasonry London), Mollier Pierre (Library - Archives - Museum GODF Paris), Bernard Skalicky (Masonica Nordica, Dania), Peter Back-Vega (Masonic Museum, Austria, Rosenau), Viorel Danacu (Centrul Regional de Cercetari Francmasonice Paris - Bucuresti).

Ta historyczna wizyta u wolnomularskich źródeł cywilizacji, zapoznanie się ze zbiorami londyńskiej biblioteki wolnomularskiej, 
zwiedzanie oryginalnych obiektów i angielskich pierwodruków, wymiana informacji i atmosfera kongresu - pozwoliły stworzyć obraz działalności wolnomularstwa.

Podsumowanie całości wydarzenia z punktu widzenia wolnomularskiego można przeczytać w 72. numerze "Wolnomularza Polskiego”, w artykule Tadeusza Cegielskiego zatytułowanym 300 lat masonerii spekulatywnej w Anglii: europejscy muzealnicy w kolebce wolnomularstwa.

\title{
Bibliografia
}

Pound R., The Master Mason Slain. The Hiramic Legend in the Red Velvet Room at Chiswick, „English Heritage Historical Review” 2009, November 1, s. 154-163, http://www.maneyonline.com/doi/abs/10.1179/175201609799838438 [dostęp: 8.10.2018].

\section{IULIANA GRAŻYŃSKA}

\section{AMMLA Congress 2017 in London}

\begin{abstract}
This article summarizes the celebration of the 27th AMMLA (European Association of Museums, Libraries and Freemasonry Archive) scientific congress organized in London on the occasion of the 300th anniversary of the rise of the British Freemasonry.
\end{abstract}

Keywords: AMMLA Congress 2017, Freemasonry, Freemason's Hall, The Library and Museum of Freemasonry, Chiswick House, The Freemason Music Collection of the Poznań University Library. 
